\title{
EFISIENSI TEKNIS USAHATANI PADI SAWAH \\ (Studi Kasus pada Kelompoktani Raksa Bumi III Desa Sindangsari \\ Kecamatan Kawali Kabupaten Ciamis)
}

\author{
Oleh \\ MUHAMAD NURDIN YUSUF \\ Fakultas Pertanian Universitas Galuh Ciamis \\ Email: muhamadnurdinyusuf@yahoo.co.id
}

\begin{abstract}
Abstrak
Penelitian ini bertujuan untuk: 1) Mengidentifikasi faktor-faktor yang berpengaruh terhadap produksi pada usahatani padi sawah; 2) Mengetahui tingkat efisiensi teknis yang dicapai pada usahatani padi sawah; dan 3) Mengidentifikasi faktor-faktor yang berpengaruh terhadap inefisiensi teknis pada usahatani padi sawah. Penelitian dilaksanakan dengan menggunakan metode studi kasus pada Kelompok Tani Raksa Bumi III Desa Sindangsari Kecamatan Kawali Kabupaten Ciamis yang beranggotakan 30 orang petani yang keseluruhannya diambil sebagai sampel atau dilaksanakan sensus. Data yang digunakan meliputi data primer dan data sekunder. Data primer diperoleh melalui wawancara dengan petani serta menggunakan kuesioner yang telah dipersiapkan sebelumnya, sedangkan data sekunder diperoleh melalui penelusuran pustaka maupun dari dinas/instansi terkait. Identifikasi faktor-faktor yang berpengaruh terhadap produksi pada usahatani padi sawah dan pengukuran tingkat efisiensi teknis yang dicapai dilakukan dengan menggunakan programasi komputer Front 4.1c, sedangkan identifikasi faktor-faktor yang berpengaruh terhadap inefisiensi teknis pada usahatani padi sawah dilakukan dengan menggunakan programasi komputer SPSS ver. 16. Hasil penelitian menunjukkan bahwa: 1) Faktor-faktor yang berpengaruh terhadap produksi pada usahatani padi sawah adalah lahan, benih, pupuk, pestisida, dan tenaga kerja. Walaupun demikian, variabelvariabel tersebut pengaruhnya tidak signifikan terhadap produksi; 2) Rata-rata tingkat efisiensi teknis yang dicapai petani adalah sebesar 78,06, dengan tingkat efisiensi teknis maksimum adalah sebesar 92,87 dan minimum sebesar 49,09; 3) Faktor-faktor yang berpengaruh signifikan terhadap inefisiensi teknis padi sawah adalah umur, pendidikan, dan pengalaman menjalankan usahatani. Bertambahnya umur, meningkatnya pendidikan, serta bertambahnya pengalaman, cenderung dapat meningkatkan inefisiensi teknis petani. Sedangkan ukuran keluarga tidak berpengaruh signifikan terhadap inefisiensi teknis.
\end{abstract}

Kata kunci: padi sawah, efisiensi teknis, inefisiensi teknis

\section{PENDAHULUAN}

Sampai saat ini hampir seluruh masyarakat Indonesia masih menjadikan beras sebagai makanan pokok. Penempatan beras sebagai makanan pokok berimplikasi luas pada kebijakan komoditas lainnya seperti gula, kedelai, daging, dan sebagainya dalam berbagai aspek baik aspek ekonomi, aspek sosial, dan aspek politik. Secara politis pemerintah menempatkan beras sebagai komoditas strategis dalam pembangunan ekonomi dan swasembada beras menjadi target pembangunan. Untuk itu telah banyak program-program nasional yang berkaitan dengan upaya peningkatan produksi beras (padi), seperti Bimas dan Inmas (Bimbingan/intensifikasi Masyarakat Tani), INSUS (Intensifikasi Khusus), SUPRA INSUS, PHT (Pengendalian Hama Terpadu), Tabela (Tanam Benih Langsung). SUTPA (Sistim Usaha Terpadu), IP 300, pengembangan padi hibrida, PTT (Pengelolaan Tanaman Terpadu), IP 400, dan lain-lain. Kondisi masyarakat yang menjadikan beras sebagai makanan pokok, berdampak pada kebijakan pemerintah yang setidaknya perlu untuk memperhatikan komoditas padi dengan berbagai programprogramnya (Kusnadi, dkk., 2011).

Beras merupakan komoditas pertanian yang sangat strategis. Kekurangan beras dapat menyebabkan gizi buruk bagi masyarakat, disamping itu kekurangan beras dapat menimbulkan rawan stabilitas keamanan (Susilowati, dkk., 2011). Kebutuhan bahan pangan terutama beras akan terus meningkat sejalan dengan bertambahnya jumlah penduduk dan peningkatan konsumsi per kapita akibat peningkatan pendapatan, namun di lain pihak upaya peningkatan produksi beras saat ini terganjal oleh berbagai kendala, seperti konversi lahan sawah subur yang masih terus 


\section{AIMBAR \\ A GRIBISNIS}

ISSN 2460-4321

Volume 1・Nomor 1・Juli 2015

berjalan, penyimpangan iklim, gejala kelelahan teknologi, penurunan kualitas sumberdaya lahan yang berdampak terhadap penurun atau pelandaian produktivitas (Putra dan Tarumun, 2012).

Upaya untuk meningkatkan produksi pertanian (padi) telah banyak dilakukan baik oleh pemerintah, lembaga swadaya masyarakat, dan perguruan tinggi. Tetapi di dalam pelaksanaannya diperoleh fakta bahwa hasil potensial produksi padi berbeda dengan hasil nyata yang diperoleh petani. Perbedaan hasil ini (yield gap) secara garis besar disebabkan oleh dua faktor, yaitu faktor non-teknis dan faktor teknis. Faktor non-teknis yaitu keadaan yang menghalangi petani untuk menggunakan teknologi yang direkomendasikan. Hal-hal tersebut meliputi: (i) pengetahuan petani sebagai indikatornya adalah pengalaman petani dalam berusahatani; (ii) prasarana transportasi sebagai indikatornya adalah jarak lahan garapan dengan tempat tinggal petani. Sedangkan faktor teknis sebagai indikatornya adalah ketersediaan air irigasi. Faktor non teknis dan faktor teknis tersebut akan mempengaruhi pertimbangan petani sebagai menajer untuk mengambil keputusan dalam penggunaan input seperti bibit, pupuk, tenaga kerja, dan obat-obatan. Dengan demikian faktor-faktor non teknis dan faktor teknis bekerja secara simultan (bersamasama) akan menentukan petani dalam penggunaan pupuk, tenaga kerja efektif dan obat-obatan yang akan menentukan tingkat produksi dan produktivitas usahatani padi sawah (Laksmi, dkk., 2012).

Perkembangan produktivitas padi sawah per hektar yang melambat menunjukkan bahwa produktivitas marjinal lahan sawah hampir maksimum mendekati leveling off. Peningkatan produktivitas dari tahun ke tahun tidak stabil bahkan cenderung berfluktuasi. Kondisi produktivitas seperti ini dapat ditingkatkan melalui upaya intensifikasi atau perbaikan teknologi. Upaya ini lebih memungkinkan mengingat peningkatan produksi melalui ekstensifikasi atau perluasan lahan sawah semakin tidak efisien. Keterbatasan anggaran pemerintah untuk pembukaan lahan irigasi dan tingginya kompetisi penggunaan lahan untuk kegiatan non pertanian, berdampak pada peningkatan produksi padi melalui perluasan lahan sawah menjadi semakin mahal. Alternatif yang perlu dipikirkan adalah meningkatkan produktivitas lahan melalui efisiensi.

Peningkatan produktivitas melalui efisiensi teknis menjadi penting untuk diperhatikan. Upaya-upaya peningkatan produksi beras nasional melalui jalur ekstensifikasi tampaknya semakin sulit karena terbatasnya penyediaan lahan pertanian produktif dan konversi lahan dari pertanian ke nonpertanian sulit dibendung karena berbagai alasan. Upaya peningkatan produksi beras melalui efisiensi teknis menjadi pilihan yang tepat. Efisiensi teknis usahatani padi di Indonesia diduga masih dapat ditingkatkan karena tingkat efisiensi teknis usahatani padi menurut penelitian sebelumnya berada pada kisaran 50 - 90 persen (Kusnadi, dkk., 2011).

\section{TINJAUAN PUSTAKA}

Coelli, et al, (2005) mengajukan model fungsi produksi frontier stokhastik dimana nilai output dibatasi dari atas oleh variabel acak stokhastik (misalnya, $\exp \left(\mathrm{x}_{\mathrm{i}}{ }_{\mathrm{i}} \beta+\mathrm{v}_{\mathrm{i}}\right)$. Kesalahan acak $v_{i}$ dapat bernilai positif atau negatif sehingga output frontier stokhastik bervariasi sekitar model deterministik, exp $\left(\mathrm{x}_{\mathrm{i}}{ }^{\beta}\right)$. Model fungsi produksi tersebut adalah:

$$
\operatorname{lnq}_{i}=x_{i}^{\prime} \beta+v_{i}-u_{i}
$$

Pendekatan pengukuran efisiensi teknis yang berorientasi output dapat dilakukan dengan menggunakan persamaan berikut:

$$
\begin{gathered}
T E_{i}=\frac{q_{i}}{\exp \left(x_{i}^{\prime} \beta+v_{i}\right)}=\frac{\exp \left(x_{i}^{\prime} \beta+v_{i}-u_{i}\right)}{\exp \left(x_{i}^{\prime} \beta+v_{i}\right)} \\
=\exp \left(-u_{i}\right)
\end{gathered}
$$

Apabila efisiensi teknis dari kegiatan ke-i didefinisikan sebagai $\quad \mathrm{TE}_{\mathrm{i}}=\exp \left(-\mathrm{u}_{\mathrm{i}}\right)$, ini melibatkan pengaruh inefisiensi teknis, $\mathrm{u}_{\mathrm{i}}$, yang tidak dapat diobservasi. Meskipun jika nilai sebenarnya dari vektor parameter, $\beta$, pada model persamaan (2.1) diketahui, hanya perbedaan, $e_{i} \equiv v_{i}-u_{i}$, yang dapat diobservasi. Prediktor terbaik untuk $\mathrm{u}_{\mathrm{i}}$ adalah harapan kondisional dari $\mathrm{u}_{\mathrm{i}}$, yang diberikan oleh nilai dari $\mathrm{v}_{\mathrm{i}}-\mathrm{u}_{\mathrm{i}}$.

Model yang dikemukakan oleh Battese dan Coelli (1995) dalam Coelli, et al (1998) mengenai pengaruh spesifik inefisiensi teknis pada model frontier stokhastik yang diasumsikan bersifat bebas (tetapi tidak identik) 


\section{Efisiensi Teknis Usahatani Padi Sawah \\ (Studi Kasus pada Kelompoktani Raksa Bumi III Desa Sindangsari \\ Kecamatan Kawali Kabupaten Ciamis) \\ MUHAMAD NURDIN YUSUF}

dari variabel acak non-negatif. Untuk kegiatan ke-i pada periode ke-t, pengaruh inefisiensi teknis, $\mathrm{u}_{\mathrm{it}}$, ditentukan oleh distribusi $\mathrm{N}\left(\mathrm{u}_{\mathrm{it}}, \sigma^{2}\right)$, dimana:

$$
\mu_{\mathrm{it}}=\mathrm{z}_{\mathrm{it}} \delta
$$

Dimana $z_{i t}$ adalah sebuah vektor $(1 \mathrm{xM})$ dari variabel penjelas yang diobservasi, yang mempunyai nilai konstan, dan $\delta$ adalah sebuah vektor (Mx1) dari parameter skalar yang tidak diketahui yang akan diestimasi.

Penelitian Idiong (2007) menunjukkan bahwa efisiensi teknis yang dicapai pada usahatani padi berkisar antara 0,48 sampai 0,99, dengan rata-rata 0,77 . Faktor-faktor yang berpengaruh terhadap produksi pada usahatani padi adalah tenaga kerja, ukuran usahatani dan benih.

Penelitian Abedullah, et al (2007) menunjukkan bahwa nilai maksimum dan minimum dari efisiensi teknis adalah 98 dan 53 persen. Rata-rata efisiensi tekis pada produksi padi adalah 91 persen. Faktor-faktor yang berpengaruh terhadap produksi pada usahatani padi adalah lahan, jam membajak, jam irigasi, jam tenaga kerja, pupuk dan dummy lokasi; sedangkan faktor-faktor yang berpengaruh terhadap inefisiensi teknis adalah umur, pendidikan, luas lahan dan dummy traktor.

Penelitian Narala dan Zala (2010) menunjukkan bahwa efisiensi teknis yang dicapai pada usahatani padi berkisar dari 71,39 persen sampai 99,82 persen dengan rata-rata 72,78 persen. Faktor-faktor yang berpengaruh terhadap produksi adalah pupuk dan pestisida.

Penelitian Isyanto (2011) menunjukkan bahwa faktor-faktor yang berpengaruh terhadap inefisiensi teknis pada usahatani padi adalah jam kerja petani di luar pertanian dan hasil ternak, lahan usahatani, lahan kebun, hasil kebun, dan penggunaan peralatan modern.

Penelitian Tien (2011) menunjukkan bahwa tingkat efisiensi teknik, usahatani padi aplikasi pertanian organik cukup tinggi yakni di atas nilai TE (technical efficiency) 0.8. Faktorfaktor yang berpengaruh terhadap produksi adalah lahan, benih dan nutrien.

Penelitian Kusnadi, dkk. (2011) menunjukkan bahwa peningkatan efisiensi akan memberikan hasil lebih baik jika diarahkan ke luar Jawa. Lahan menjadi faktor paling responsif dalam upaya peningkatan produksi.
Faktor yang berpengaruh nyata terhadap inefisiensi yaitu umur petani, pendidikan petani, dummy musim, dummy kelompok tani, dummy status kepemilikan lahan, kepemilikan persil, dan dummy lokasi Jawa dan luar Jawa.

Penelitian Suharyanto, dkk. (2013) menunjukkan bahwa efisiensi teknis yang dicapai berkisar antara 71,60-99,28 dengan rata-rata 88,24. Faktor-faktor yang berpengaruh terhadap produksi padi adalah lahan, jumlah benih, pupuk nitrogen, pupuk organik, pestisida dan dummy musim hujan. Sedangkan factorfaktor yang berpengaruh signifikan terhadap inefisiensi teknis adalah umur, pendidikan, pengalaman dan jumlah kepemilikan lahan.

Penelitian Enwerem dan Ohajianya (2013) menunjukkan bahwa faktor-faktor yang berpengaruh terhadap output pada produksi padi adalah tenaga kerja, modal, lahan dan material tanaman. Rata-rata efisiensi teknis yang dicapai adalah 0,65 dan 0,69 untuk petani skala besar dan kecil.

Penelitian Kadiri, et al (2014) menunjukkan bahwa efisiensi teknis individual yang dicapai petani berkisar antara 0,384 dan 0,941 dengan rata-rata 0,626. Faktor-faktor yang berpengaruh terhadap produksi padi adalah lahan, benih, tenaga kerja dalam keluarga, tenaga kerja sewa, pupuk dan herbisida.

\section{HIPOTESIS}

Hipotesis yang diajukan pada penelitian ini adalah sebagai berikut:

1. Produksi padi (Y) dipengaruhi oleh lahan $\left(\mathrm{X}_{1}\right)$, benih $\left(\mathrm{X}_{2}\right)$, pupuk $\left(\mathrm{X}_{3}\right)$, tenaga kerja $\left(\mathrm{X}_{4}\right)$ dan pestisida $\left(\mathrm{X}_{5}\right)$.

2. Inefisiensi teknis (u) dipengaruhi oleh umur $\left(Z_{1}\right)$, pendidikan $\left(Z_{2}\right)$, pengalaman $\left(Z_{3}\right)$ dan ukuran keluarga $\left(\mathrm{Z}_{4}\right)$.

\section{METODE PENELITIAN}

Jenis penelitian yang digunakan dalam penelitian ini adalah studi kasus. Menurut Sugiyono (2007), studi kasus merupakan pengujian secara rinci terhadap satu latar atau satu orang subjek atau satu tempat penyimpanan dokumen atau satu peristiwa tertentu.

Kelompoktani Raksa Bumi III di Desa Sindangsari Kecamatan Kawali Kabupaten Ciamis diambil secara purposif sebagai sampel 


\section{MIMBAR \\ A GRIBISNIS}

ISSN 2460-4321

Volume 1・Nomor 1・Juli 2015

kelompoktani dengan pertimbangan bahwa kelompoktani tersebut aktif dalam kegiatan penyuluhan pertanian. Kelompoktani Raksa Bumi III memiliki anggota sebanyak 50 orang, dan keseluruhannya diambil sebagai anggota sampel atau dilaksanakan sensus.

Pengumpulan data primer melalui wawancara dengan menggunakan kuesioner yang telah dipersiapkan sebelumnya. Data primer yang dikumpulkan terdiri atas karakteristik petani (jenis kelamin, umur, pendidikan, lama sekolah, dan sebagainya), dan data produksi (input dan output pada usahatani padi sawah). Data sekunder yang digunakan pada penelitian ini diperoleh melalui penelusuran pustaka atau referensi, maupun data yang diperoleh dari dinas atau instansi terkait, antara lain BPS Kabupaten Ciamis dan Dinas Pertanian Tanaman Pangan Kabupaten Ciamis.

Variabel yang dioperasionalkan dalam penelitian ini meliputi:

1. Produksi (Y) adalah jumlah produksi padi yang dihasilkan, dan dinyatakan dalam satuan kilogram $(\mathrm{kg})$.

2. Lahan $\left(\mathrm{X}_{1}\right)$, adalah luas lahan yang digunakan pada usahatani padi sawah, dan dinyatakan dalam hektar (ha).

3. Benih $\left(\mathrm{X}_{2}\right)$, adalah jumlah benih yang digunakan pada usahatani padi sawah, dan dinyatakan dalam satuan kilogram $(\mathrm{kg})$.

4. Pupuk $\left(\mathrm{X}_{3}\right)$, adalah jumlah pupuk yang digunakan pada usahatani padi sawah, dan dinyatakan dalam satuan kilogram $(\mathrm{kg})$.

5. Tenaga kerja $\left(\mathrm{X}_{4}\right)$ adalah jumlah tenaga kerja yang digunakan, dan dinyatakan dalam satuan hari orang kerja (HOK).

6. Pestisida $\left(\mathrm{X}_{5}\right)$, adalah jumlah pestisida yang digunakan pada usahatani padi sawah, dan dinyatakan dalam satuan liter (ltr).

7. Efisiensi teknis (ET) yang dimaksud dalam penelitian ini adalah perbandingan antara faktor produksi (input) yang digunakan dengan output yang dihasilkan.

8. Inefisiensi teknis (u) adalah inefisiensi teknis yang diperoleh dari hasil analisis fungsi produksi frontier stokastik.

9. Umur $\left(Z_{1}\right)$, adalah umur petani padi sawah, dan diukur dalam satuan tahun (tahun).
10. Pendidikan $\left(\mathrm{Z}_{2}\right)$, adalah pendidikan formal yang pernah diikuti oleh petani padi sawah, dan diukur dalam satuan tahun (tahun).

11. Pengalaman $\left(\mathrm{Z}_{3}\right)$, adalah lamanya pengalaman petani dalam usahatani padi sawah, dan diukur dalam satuan tahun (tahun).

12. Ukuran keluarga $\left(\mathrm{Z}_{4}\right)$, adalah banyaknya anggota keluarga petani padi sawah, yang diukur dalam satuan orang (orang).

Analisis faktor-faktor yang berpengaruh terhadap produksi pada usahatani padi sawah dilakukan dengan menggunakan persamaan berikut:

$\ln Y=\beta_{0}+\beta_{1} \ln X_{1}+\beta_{2} \ln X_{2}+\beta_{3} \ln X_{3}+\beta_{4} \ln X_{4}$ $+\beta_{5} \ln X_{5}+v_{i}-u_{i}$

Dimana:

$\mathrm{Y}=$ Produksi $(\mathrm{kg})$

$\mathrm{X}_{1}=$ Lahan (ha)

$X_{2}=$ Benih $(\mathrm{kg})$

$\mathrm{X}_{3}=$ Pupuk $(\mathrm{kg})$

$\mathrm{X}_{4}=$ Tenaga kerja (HOK)

$\mathrm{X}_{5}=$ Pestisida (liter)

$\beta=$ Koefisien regresi

Pendugaan parameter menggunakan program Frontier versi 4.1c.

Pendekatan yang digunakan dalam mengukur tingkat efisiensi teknis yang dicapai pada usahatani padi sawah adalah dengan menggunakan persamaan berikut:

$$
T E_{i}=\frac{Y_{i}}{Y_{i}^{*}}=\frac{\exp \left(x_{i} \beta+v_{i}-u_{i}\right.}{\exp \left(x_{i} \beta+v_{i}\right)}=\exp \left(-u_{i}\right)
$$

Pendugaan parameter menggunakan program Frontier versi 4.1c.

Faktor-faktor yang berpengaruh terhadap inefisiensi teknis pada usahatani padi sawah dianalisis dengan menggunakan persamaan berikut:

$$
\mu_{i}=\delta_{0}+\delta_{1} Z_{1}+\delta_{2} Z_{2}+\delta_{3} Z_{3}+\delta_{4} Z_{4}
$$

Dimana:

$\mu_{\mathrm{i}}=$ Inefisiensi teknis

$\mathrm{Z}_{1}=$ Umur (tahun)

$\mathrm{Z}_{2}=$ Pendidikan (tahun)

$Z_{3}=$ Pengalaman (tahun)

$\mathrm{Z}_{4}=$ Ukuran keluarga (orang)

$\delta=$ Koefisien regresi 


\section{Efisiensi Teknis Usahatani Padi Sawah \\ (Studi Kasus pada Kelompoktani Raksa Bumi III Desa Sindangsari \\ Kecamatan Kawali Kabupaten Ciamis)}

MUHAMAD NURDIN YUSUF

Pendugaan parameter menggunakan program SPSS ver. 16.

Pengujian efisiensi teknis terkait dengan pengujian ada tidaknya efek inefisiensi. Apabila tidak ada efek inefisiensi atau $\gamma=0$, berarti petani telah melaksanakan usahataninya secara efisiens atau tingkat efisiensi sama dengan satu. Akan tetapi jika secara statistik $\gamma \neq 0$, berarti terjadi inefisiensi dalam usahanya sehingga masih ada peluang bagi petani untuk meningkatkan efisiensinya secara maksimal sebesar tingkat inefisiensi yang terjadi.

Ada tidaknya efek inefisiensi teknis dilakukan dengan pengujian hipotesis yang dinyatakan sebagai: $\mathrm{H}_{0}: \gamma=\delta_{1}=\delta_{2}=\ldots \ldots=\delta_{\mathrm{m}-1}$ $=0$, dan $\gamma$ diformulasikan sebagai: $\gamma=$ $\delta^{2}{ }_{u} /\left(\delta^{2}{ }_{u}+\delta^{2}{ }_{v}\right)$. Hipotesis diterima jika nilai statistik uji-LR lebih kecil atau sama dengan nilai kritis distribusi $\chi^{2}$ dari Tabel Kodde dan Palm (1986). Jika hipotesis diterima, berarti tidak mengindikasikan adanya efek inefisiensi teknis. Tidak ada penyimpangan pada produksi frontier yang terkait dengan inefisiensi teknis, melainkan hanya terkait dengan kesalahan stokhastik. Sementara pengujian signifikansi parameter determinan inefisiensi teknis dilakukan baik secara bersama dengan uji-LR atau pun secara individual dengan uji-t. Pengujian signifikansi parameter secara keseluruhan dinyatakan sebagai: $\mathrm{Ho}=\delta_{1}=\ldots .=$ $\delta_{\mathrm{m}-1}=0$. Jika Ho ditolak, maka uji signifikansi parameter perlu dilanjutkan dengan uji-t untuk mengidentifikasi faktor-faktor determinan yang berpengaruh secara signifikan terhadap inefisiensi teknis.

\section{HASIL DAN PEMBAHASAN}

\section{Faktor-Faktor Yang Berpengaruh Terhadap Produksi Pada Usahatani Padi Sawah}

Fungsi produksi frontier stokastik yang digunakan adalah model Cobb-Douglas yang ditransformasikan ke dalam bentuk linear logaritma natural. Estimasi fungsi produksi dilakukan dengan memasukkan beberapa variabel, yaitu output berupa produksi padi yang diukur dalam satuan kilogram $(\mathrm{kg})$. Input meliputi lahan (ha), benih (kg), pupuk (kg), pestisida (liter), dan tenaga kerja (HOK).

Estimasi fungsi produksi frontier stokastik dilakukan dengan menggunakan program Frontier 4.1c sehingga diperoleh estimasi dengan metode Maximum Likelihood Estimation (MLE) sebagaimana disajikan pada Tabel 1 sebagai berikut :

Tabel 1. Hasil Estimasi Fungsi Produksi dengan Metode MLE

\begin{tabular}{|l|c|c|c|r|}
\hline \multicolumn{1}{|c|}{ Variabel } & Parameter & Koefisien & $\begin{array}{c}\text { Standar } \\
\text { Error }\end{array}$ & \multicolumn{1}{c|}{ t-ratio } \\
\hline Konstanta & $\beta_{0}$ & 0,2739 & 0,9826 & 0,2788 \\
Lahan & $\beta_{1}$ & 0,4113 & 0,6028 & 0,6824 \\
Benih & $\beta_{2}$ & 0,3137 & 0,8234 & 0,3810 \\
Pupuk & $\beta_{3}$ & 0,5662 & 0,5867 & 0,9650 \\
Pestisida & $\beta_{4}$ & 0,6235 & 0,8981 & 0,6943 \\
Tenaga kerja & $\beta_{5}$ & $-0,1035$ & 0,8773 & $-0,1180$ \\
Sigma square & $\sigma^{2}$ & 0,1215 & 0,2829 & 0,4296 \\
Gamma & $\gamma$ & 0,9940 & 0,2873 & 0,3459 \\
\hline Log likelihood function & \multicolumn{4}{|c|}{$=-0,2011$} \\
LR Test & $=0,1365$ \\
\hline
\end{tabular}

Sumber: Analisis Data Primer, 2014

Keterangan:

$* * *, * *, *$ masing-masing menunjukkan signifikansi pada $\alpha 1 \%(2,704), 5 \%(2,021)$, dan $10 \%(1,684)$

Nilai taksiran parameter $\gamma$ dalam model secara statistik berbeda dari nol walaupun tidak signifikan. Statistik LR-Test untuk parameter $\gamma$ sebesar 0,1365 yang lebih tinggi jika dibandingkan dengan nilai kritis pada Tabel Kodde dan Palm menunjukkan bahwa ada efek inefisiensi teknis dalam model yang bersifat stokhastik. Fakta ini menunjukkan bahwa petani padi sawah di Kelompoktani Raksabumi
III Desa Sindangsari Kecamatan Kawali belum efisien secara penuh (full-efficient) dalam melaksanakan usahanya.

Nilai taksiran parameter $\gamma$ sebesar 0,9940 menunjukkan bahwa menunjukkan bahwa error term hanya berasal dari akibat inefisiensi $\left(\mathrm{u}_{\mathrm{i}}\right)$ dan bukan berasal dari noise $\left(\mathrm{v}_{\mathrm{i}}\right)$. Model ini cukup baik karena nilai $\gamma$ yang mendekati 1 . Sedangkan jika $\gamma$ mendekati nol 


\section{MIIMBAR \\ A GRIBISNIS}

ISSN 2460-4321

Volume 1・ Nomor 1・Juli 2015

diinterpretasikan bahwa seluruh error term adalah sebagai akibat dari noise $\left(\mathrm{v}_{\mathrm{i}}\right)$ seperti cuaca, hama dan penyakit, dan sebagainya bukan akibat dari inefisiensi. Jika demikian maka parameter koefisien inefisiensi menjadi tidak bermakna.

Tabel 2 menunjukkan bahwa semua variabel yang diteliti tidak berpengaruh signifikan terhadap hasil produksi. Nilai koefisien variabel lahan bertanda positif menunjukkan bahwa produksi dapat ditingkatkan jika ada penambahan lahan usahatani. Nilai koefisien lahan sebesar 0,4113 menunjukkan bahwa penambahan 1 persen lahan akan meningkatkan produksi sebesar 0,41 persen. Hal tersebut sejalan dengan penelitian Rosihan dan Siska (2009), Muhaimin A.W (2012).

Nilai koefisien benih bertanda positif menunjukkan bahwa produksi dapat ditingkatkan jika ada penambahan benih yang digunakan. Nilai koefisien benih sebesar 0,3137 menunjukkan bahwa penambahan 1 persen benih bertendensi meningkatkan produksi sebesar 0,31 persen. Dengan demikian petani mempunyai kesempatan untuk dapat meningkatkan produksinya dengan menggunakan benih bersertifikat. Hal tersebut sejalan dengan penelitian Kurniawan (2009), Muhaimin A.W (2012).

Nilai koefisien pupuk bertanda positif, hal ini menunjukkan bahwa produksi dapat ditingkatkan jika penggunaan pupuk ditambah. Nilai koefisien pupuk sebesar 0,5662 yang menunjukkan bahwa penambahan 1 persen pupuk bertendensi meningkatkan produksi sebesar 0,57 persen.

Nilai koefisien variabel pestisida bertanda positif menunjukkan bahwa produksi dapat ditingkatkan jika ada penambahan penggunaan pestisida. Nilai koefisien pestisida sebesar 0,6235 menunjukkan bahwa penambahan 1 persen penggunaan pestisida cenderung meningkatkan produksi sebesar 0,62 persen. Dengan demikian petani mempunyai kesempatan untuk meningkatkan produksinya dengan cara menambah penggunaan pestisida. Walaupun demikian, petani perlu mempertimbangkan adanya kenaikan biaya produksi akibat penambahan penggunaan pestisida ini.
Nilai koefisien variabel tenaga kerja bertanda negatif menunjukkan bahwa produksi dapat ditingkatkan jika ada pengurangan tenaga kerja. Nilai koefisien tenaga kerja sebesar 0,1035 menunjukkan bahwa dengan mengurangi 1 persen penggunaan tenaga kerja cenderung meningkatkan produksi sebesar 0,10 persen.

Hasil penelitian ini mengungkap bahwa faktor-faktor yang mempengaruhi produksi pada usahatani padi sawah di Kelompoktani Raksabumi III Desa Sindangsari Kecamatan Kawali Kabupaten Ciamis adalah lahan, benih, pupuk, pestisida, dan tenaga kerja. Petani dapat meningkatkan produksinya dengan cara menambah lahan, menggunakan benih bersertifikat, menambah penggunaan pupuk, menambah penggunaan pestisida, serta mengurangi tenaga kerja.

\section{Tingkat Efisiensi Teknis Yang Dicapai Pada Usahatani Padi Sawah}

Efisiensi teknis usahatani padi sawah dimaksudkan untuk mengukur berapa tingkat produksi yang dapat dicapai dari potensi produksi yang mungkin dapat dicapai oleh petani. Estimasi efisiensi teknis usahatani padi sawah dilakukan dengan menggunakan program Frontier 4.1c dari Coelli, et al, (2005). Program Frontier 4.1c ini memiliki kelebihan yaitu disamping dapat menganalisis fungsi produksi, juga sekaligus dapat menghitung efisiensi teknisnya. Hasil estimasi efisiensi teknis usahatani padi sawah dapat dilihat pada Tabel 3.

Tabel 3. Distribusi Efisiensi Teknis Usahatani Padi Sawah

\begin{tabular}{|c|c|}
\hline $\begin{array}{c}\text { Rentang Efisiensi } \\
\text { Teknis (\%) }\end{array}$ & Frekuensi \\
\hline $41-50$ & 1 \\
\hline $51-60$ & 1 \\
\hline $61-70$ & 9 \\
\hline $71-80$ & 14 \\
\hline $81-90$ & 23 \\
\hline \multicolumn{2}{|c|}{2} \\
\hline Rata-rata tingkat efisiensi teknis & $=$ \\
Standar deviasi & $=$ \\
Minimum & $=$ \\
Maksimum & $9,69,06$ \\
& $=$ \\
\hline
\end{tabular}

Sumber: Data primer diolah, 2013 


\section{Efisiensi Teknis Usahatani Padi Sawah \\ (Studi Kasus pada Kelompoktani Raksa Bumi III Desa Sindangsari \\ Kecamatan Kawali Kabupaten Ciamis)}

MUHAMAD NURDIN YUSUF

Tabel 3 menunjukkan bahwa petani yang mencapai efisiensi teknis di atas 71 persen sebanyak 39 orang dan sedangkan yang mencapai efisiensi teknis di bawah 71 persen sebanyak 11 orang.

Nilai efisiensi teknis terendah yang dicapai oleh petani sebesar 49,09 dan tertinggi sebesar 92,87 , dengan rata-rata 78,06 . Nilai efisiensi teknis ini menunjukkan bahwa secara rata-rata petani padi sawah mampu mencapai 78,06 persen dari produksi potensial yang dihasilkan dengan input yang dikorbankan menggunakan teknologi yang ada. Hal ini memberi indikasi bahwa dalam jangka pendek masih ada peluang bagi petani untuk meningkatkan produksinya sebesar 21,94 persen yang dapat dicapai dengan penerapan sistem pengelolaan yang terbaik menggunakan teknologi yang ada.

Rata-rata efisiensi teknis sebesar 78,06 menunjukkan adanya kesenjangan inefisiensi (inefficiency gap) sebesar 21,94. Implikasinya adalah bahwa 21,94 persen produksi yang lebih tinggi dapat dicapai tanpa menggunakan tambahan input, atau penggunaan input dapat dikurangi untuk mencapai tingkat output yang sama.

Nilai efisiensi teknis yang diperoleh menunjukkan bahwa rata-rata petani untuk dapat mencapai tingkat efisiensi teknis yang tertinggi yang dicapai oleh petani lainnya, mereka dapat menghemat sekitar 21,94 persen untuk dapat mencapai efisiensi teknis tertinggi yang dicapai oleh petani lainnya.

Menurut Sukiyono (2004), perbedaan tingkat efisiensi teknis yang dicapai oleh petani mengindikasikan tingkat penguasaan dan aplikasi teknologi berusahatani yang berbedabeda. Tingkat penguasaan teknologi yang berbeda disamping disebabkan oleh atribut yang melekat pada petani seperti tingkat pendidikan dan umur, juga disebabkan oleh faktor eksternal seperti kurangnya penyuluhan.
Belbase dan Grabowski (1985) dan Shapiro (1983) menyatakan bahwa usaha untuk meningkatkan efisiensi akan lebih efisien dari sisi biaya dibandingkan dengan introduksi teknologi baru sebagai sarana meningkatkan produktivitas pertanian, jika petani belum menggunakan teknologi yang efisien.

\section{Faktor-Faktor Berpengaruh Terhadap Inefisiensi Teknis Pada Usahatani Padi Sawah}

Identifikasi faktor-faktor yang mempengaruhi inefisiensi teknis pada usahatani padi sawah dapat membantu pembuat kebijakan dalam merumuskan program yang tepat dan sesuai dengan kondisi petani. Diasumsikan bahwa determinan inefisiensi teknis ditentukan oleh pengetahuan dan keterampilan tentang teknologi yang pengaplikasiannya di lapangan tergantung pada faktor internal yang berkaitan dengan kemampuan manajerial petani.

Pengetahuan mengenai tingkat inefisiensi teknis sangat penting untuk mengetahui faktorfaktor yang menyebabkan terjadinya inefisiensi teknis tersebut sehingga dapat dilakukan upaya pengurangan tingkat inefisiensi teknis yang dapat meningkatkan efisiensi teknis, yang berarti pula akan terjadi peningkatan produksi dan produktivitas.

Sumber inefisiensi teknis pada umumnya berkaitan dengan kemampuan manajerial petani. Dalam penelitian ini, kemampuan manajerial petani didekati dengan sejumlah karakteristik petani yang meliputi: umur, pendidikan, pengalaman menjalankan usahatani, dan ukuran keluarga.

Estimasi faktor-faktor penentu inefisiensi teknis pada usahatani padi sawah dilakukan dengan menggunakan programasi komputer SPSS ver. 16. Hasil estimasi faktor penentu inefisiensi teknis usahatani padi sawah dapat dilihat pada Tabel

4.

Tabel 4. Hasil Estimasi Fungsi Inefisiensi dengan Metode OLS

\begin{tabular}{|c|c|c|c|c|c|}
\hline Variabel & Parameter & Koefisien & Standar Error & t-ratio & Sig \\
\hline Konstanta & $\delta_{0}$ & $-0,894$ & 1,628 & $-0,549$ & 0,586 \\
\hline Umur & $\delta_{1}$ & $-1,088$ & 0,462 & $-2,356$ & 0,023 \\
\hline Pendidikan & $\delta_{2}$ & 0,719 & 0,176 & 4,080 & 0,000 \\
\hline Pengalaman & $\delta_{3}$ & 0,796 & 0,207 & 3,848 & 0,000 \\
\hline Ukuran keluarga & $\delta_{4}$ & 0,181 & 0,148 & $-1,227$ & 0,226 \\
\hline $\begin{array}{l}\mathrm{R}^{2}=0,456 \\
\text { Adj. } \mathrm{R}^{2}=0,408 \\
\text { F-hitung }=9,440\end{array}$ & & & & & \\
\hline
\end{tabular}

Sumber : Analisis Data Primer, 2014 


\section{MIIMBAR \\ A GRIBISNIS}

ISSN 2460-4321

Volume 1 • Nomor 1 • Juli 2015

Hasil penelitian menunjukkan bahwa sumber inefisiensi teknis secara bersama-sama berpengaruh signifikan terhadap tingkat inefisiensi teknis usahatani padi sawah. Variabel umur, pendidikan, dan pengalaman berpengaruh signifikan terhadap tingkat inefisiensi teknis, sedangkan variabel tanggungan keluarga tidak berpengaruh signifikan.

Koefisien regresi variabel umur bertanda negatif namun signifikan pada taraf 5 persen. Hal ini menunjukkan bahwa petani yang berumur lebih muda, secara teknis tidak efisien dibandingkan dengan petani yang berumur lebih tua. Hal ini kemungkinan dapat disebabkan bahwa petani yang berumur lebih muda cenderung mempunyai pengalaman usahatani yang kurang sehingga bertendensi pada peningkatan berkurangnya produktivitas kerja. Hasil penelitian ini sejalan dengan hasil penelitian Bamiro, et al., (2006), Alabi dan Aruna (2005), dan Serin, et al., (2008).

Rata-rata umur petani adalah 44 tahun, dengan umur termuda 31 tahun dan tertua 58 tahun. Menurut Hermanto (1996) dalam Iriani (2005), tingkat umur produktif yaitu antara 15 55 tahun, sedangkan umur yang tidak produktif berada di bawah 15 dan di atas 55 tahun. Jika digunakan klasifikasi umur tersebut, maka ratarata efisiensi teknis dari petani yang berumur sampai dengan 55 tahun sebesar 0,75, sedangkan rata-rata efisiensi teknis yang dicapai oleh petani yang berumur lebih dari 55 tahun sebesar 0,79.

Koefisien regresi variabel pendidikan bertanda positif dan signifikan pada taraf 5 persen dan 1 persen. Hal ini menunjukkan bahwa petani yang berpendidikan lebih tinggi, tingkat inefisiensi teknisnya cenderung tinggi. Hasil penelitian ini sejalan dengan hasil penelitian dari Mor dan Sharma (2012), Bamiro, et al (2006), Dung, et al (2011), Chang dan Villano (2008), Udoh dan Etim (2009), Serin, et al (2008), dan Ogunyinka dan Ajibefun (2004).

Sarwono (2001) menyatakan bahwa tingkat pendidikan yang baik cenderung mudah untuk menerima informasi baru dalam teknik bertani yang baik, selain memberikan tanggapan positif pada setiap kemajuan usahatani juga lebih matang untuk memecahkan setiap permasalahan yang dihadapinya.
Koefisien regresi variabel pengalaman menjalankan usahatani bertanda positif dan signifikan pada taraf 5 persen dan 1 persen. Hasil ini menunjukkan bahwa semakin lama pengalaman menjalankan usahatani maka akan semakin tinggi tingkat inefisiensi teknis yang dicapai, atau semakin rendah efisiensi teknisnya. Hal ini disebabkan bahwa semakin lama pengalaman petani maka akan semakin resisten di dalam menerima inovasi teknologi baru karena petani cenderung sudah merasa nyaman dengan sistem usahatani padi sawah yang selama ini dilaksanakannya. Hasil penelitian ini sejalan dengan hasil penelitian Yuniawan A.Y (2011), Suslinawati (2011).

Hernanto (1996) menyatakan bahwa pengalaman usahatani merupakan modal penting untuk berhasilnya suatu kegiatan usahatani. Berbedanya tingkat pengalaman masing-masing petani maka akan berbeda pula pola pikir mereka dalam menerapkan inovasi pada kegiatan usahataninya. Penerapan teknologi dan manajemen yang baik akan mempengaruhi perilaku berusaha petani dalam menjalankan usahataninya.

Koefisien regresi variabel ukuran keluarga berpengaruh positif walaupun tidak signifikan. Hal ini menunjukkan bahwa semakin banyak jumlah anggota keluarga maka akan semakin tinggi tingkat inefisiensi teknisnya atau semakin banyak jumlah anggota keluarga semakin rendah tingkat efisiensi teknis yang dapat dicapainya. Hasil ini sejalan dengan hasil penelitian Haider, et al., (2011), Muhaimin (2012).

Makin banyak jumlah tanggungan keluarga, maka makin besar pula beban yang ditanggung oleh kepala keluarga, sebaliknya makin kecil jumlah anggota keluarga tentu beban yang akan ditanggung akan semakin kecil pula (Yasin dan Ahmad, 1996). Besarnya jumlah anggota keluarga menyebabkan petani mencari tambahan penghasilan di luar usahataninya sehingga mengurangi curahan waktu kerjanya di usahatani padi sawah yang mengakibatkan penurunan efisiensi.

Hasil penelitian ini mengungkap bahwa faktor-faktor yang berpengaruh signifikan terhadap inefisiensi teknis adalah umur, pendidikan, dan pengalaman menjalankan usahatani. Bertambahnya umur, meningkatnya pendidikan, serta bertambahnya pengalaman, 


\section{Efisiensi Teknis Usahatani Padi Sawah \\ (Studi Kasus pada Kelompoktani Raksa Bumi III Desa Sindangsari \\ Kecamatan Kawali Kabupaten Ciamis) \\ MUHAMAD NURDIN YUSUF}

cenderung dapat meningkatkan inefisiensi teknis petani.

\section{PENUTUP}

\section{Simpulan}

Berdasarkan pada hasil dan pembahasan, maka dapat disimpulkan sebagai berikut:

1. Faktor-faktor yang berpengaruh terhadap produksi pada usahatani padi sawah adalah lahan, benih, pupuk, pestisida, dan tenaga kerja. Walaupun demikian, variabelvariabel tersebut pengaruhnya tidak signifikan terhadap produksi.

2. Rata-rata tingkat efisiensi teknis yang dicapai petani padi sawah di Kelompoktani Raksabumi III Desa Sindangsari Kecamatan Kawali Kabupaten Ciamis adalah sebesar 78,06, dengan tingkat efisiensi teknis maksimum adalah sebesar 92,87 dan minimum sebesar 49,09.

3. Faktor-faktor yang berpengaruh signifikan terhadap inefisiensi teknis padi sawah adalah umur, pendidikan, dan pengalaman menjalankan usahatani. Bertambahnya umur, meningkatnya pendidikan, serta bertambahnya pengalaman, cenderung dapat meningkatkan inefisiensi teknis petani. Sedangkan ukuran keluarga tidak berpengaruh signifikan terhadap inefisiensi teknis.

\section{DAFTAR PUSTAKA}

Abedullah, Kouser, S., dan Mushtaq, K. 2007. Analysis Of Technical Efficiency Of Rice Production In Punjab (Pakistan): Implications For Future Investment Strategies. Pakistan Economic And Social Review, 45(2): 231-244.

Akanbi, U. O., Omotesho, O. A. and Ayinde, O. E. 2011. Analysis of Technical Efficiency of Rice Farms in Duku Irrigation Scheme Kwara State, Nigeria. Nigerian Journal of Agriculture, Food and Environment, 7(3): 65-72.

Akighir, D.T., dan Shabu, T. 2011. Efficiency of Resource use in Rice Farming Enterprise in Kwande Local Government Area of Benue State, Nigeria. International Journal of Humanities and Social Science, 1(3): 215-220.
Asmara, R. dan Sugianto, S.K. 2009. Analisis Efisiensi Teknis Pada Usahatani Tebu. Habitat, XX (1): 62-72.

Badan Pusat Statistik Kabupaten Ciamis. 2014. Kawali Dalam Angka Tahun 2014. Ciamis. BPS.

Coelli, T., Rao, D.S.P., dan Battese, G.E. 2005. An Introduction to Efficieny and Productivity Analysis. Kluwer Academic Publishers, Boston-Dordrecht-London.

Donkoh, S.A., Ayambila, S., dan Abdulai, S. 2013. Technical Efficiency of Rice Production at the Tono Irrigation Scheme in Northern Ghana. American Journal of Experimental Agriculture, 3(1): 25-42.

Enwerem, V.A. dan Ohajianya, D.O. 2013. Farm Size and Technical Efficiency of Rice Farmers in Imo State, Nigeria Greener Journal of Agricultural Sciences, 3(2): 128-136.

Idiong, I.C. 2007. Estimation of Farm Level Technical Efficiency in Smallscale Swamp Rice Production in Cross River State of Nigeria: A Stochastic Frontier Approach. World Journal of Agricultural Sciences, 3 (5): 653-658.

Isyanto, A.Y. 2011. Faktor-faktor yang Mempengaruhi Inefisiensi Teknik pada Usahatani Padi di Kabupaten Ciamis. Cakrawala Galuh, I (5): 31-40.

Kadiri, F.A., Eze, C.C, Orebiyi, J.S; Lemchi, J.I, Ohajianya, D.O, dan Nwaiwu, I.U. 2014. Technical Efficiency In Paddy Rice Production In Niger Delta Region Of Nigeria. Global Journal of Agricultural Research, 2(2): 33-43.

Kusnadi, N., Tinaprilla, N., Susilowati, S.H., dan Purwoto, A. 2011. Analisis Efisiensi Usahatani Padi di Beberapa Sentra Produksi Padi di Indonesia. Jurnal Agro Ekonomi, 29(1): 25-48.

Kurniawan, A.Y. 2010. Faktor-Faktor Yang Mempengaruhi Efisiensi Teknis Pada Usahatani Padi Lahan Pasang Surut di Kecamatan Anjir Muara Kabupaten Barito Kuala Kalimantan Selatan. EPP, 7(2): 2329.

Laksmi, N.M.A.C., Suamba, I.K., dan Ambarawati, I.G.A.A. 2012. Analisis Efisiensi Usahatani Padi Sawah (Studi Kasus di Subak Guama, Kecamatan 


\section{AIMBAR \\ Agribisnis \\ ISSN 2460-4321}

Volume 1・Nomor 1・Juli 2015

Marga, Kabupaten Tabanan). E-Journal Agribisnis dan Agrowisata, 1(1): 34-44.

Muhaimin, A.W. 2012. Analisis Efisiensi

Teknis Faktor Produksi Padi (Oryza Sativa) Organik di Desa Sumber Pasir, Kecamatan Pakis, Kabupaten Malang. Agrise. XII(3): 193-198.

Narala, A., dan Zala, Y.C. 2010. Technical Efficiency of Rice Farms under Irrigated Conditions in Central Gujarat. Agricultural Economics Research Review, Vol. 23, July-December 2010: 375-381.

Prayoga, A. 2010. Produktivitas dan Efisiensi Teknis Usahatani Padi Organik Lahan Sawah. Jurnal Agro Ekonomi, 28(1): 1-19.

Putra, E., dan Tarumun, S. 2012. Analisis Faktor-faktor Produksi Padi Study Kasus Operasi Pangan Riau Makmur di Kabupaten Kampar. Indonesian Journal of Agricultural Economics, 3(2): 117-134.

Sugiyono. 2007. Statistik Untuk Penelitian, Bandung. Alfabeta.

Suslinawati. 2011. Pendugaan Fungsi Produksi Usahatani Padi Lahan Pasang Surut (Kasus Pada Sentra Yang Berpotensi Terdampak Oleh Perubahan Iklim). Media Sains, 3(1): 9-19. 